DOI: $10.17516 / 1997-1370-0633$

УДК 303.686 .5

\title{
Study of Recreation Forms During the Period of the Great Patriotic War by the Method of Oral History
}

\author{
Olga L. Lushnikovaa and Viktor K. Lushnikov*b \\ ${ }^{a}$ Khakass Research Institute of Language, Literature and History \\ Abakan, Republic of Khakassia, Russian Federation \\ ${ }^{b}$ Katanov Khakass State University \\ Abakan, Republic of Khakassia, Russian Federation
}

Received 01.02.2019, received in revised form 04.06.2020, accepted 10.07.2020

\begin{abstract}
The paper concerns the recreation forms of the population of the South of Krasnoyarsk Krai during the Great Patriotic War. The purpose of this work is to give the general idea of recreation forms at that time. There are a lot of quantitative studies devoted to recreation in wartime, however, qualitative researches are more valuable for a deeper understanding of life in that period. The method of oral history is more relevant for this purpose because it allows exploring the direct people's experience in the past. The article is based on the interview data of 26 persons (aged 78-88 years) collected in the period of 2011-2017.

The analysis allowed outlining a general view of wartime recreation in the South of Krasnoyarsk Krai. Firstly, the study revealed diverse forms of recreation. These are reading books in libraries, listening to the radio, going to the theaters and circus (both local and visiting), and mobile cinemas. Evening dancing parties to live concertina, accordion or bayan music, and in some places to the brass band can be called a special form of recreation. Secondly, this study found differences between urban and rural recreation. Rural people had fewer opportunities for recreational activities. For example, in rural areas most libraries were closed due to the lack of funding. Thirdly, interpersonal communication, which allowed people to relax, to have rest and to share their experiences and emotions with other people, played a very important role.
\end{abstract}

Keywords: forms of recreation, the Great Patriotic War, oral history, memories; cultural life.

Research area: history, sociology of culture.

Citation: Lushnikova, O.L., Lushnikov, V.K. (2020). Study of recreation forms during the period of the Great Patriotic War by the method of oral history. J. Sib. Fed. Univ. Humanit. Soc. Sci., 13(7), 1153 1162. DOI: 10.17516/1997-1370-0633.

(C) Siberian Federal University. All rights reserved

* Corresponding author E-mail address: oltolt@mail.ru, viktorlushnikov@yandex.ru ORCID: 0000-0002-1440-1505 (Lushnikova); 0000-0002-7832-2064 (Lushnikov) 


\section{Introduction}

The Great Patriotic War is one of the most significant events in the $20^{\text {th }}$ century. There are many studies devoted to this issue in historical, anthropological, and cultural sciences. However, the scientific construction of the war is not enough. Rational scientific theories with logical explanation do not allow understanding the real people's life: their opinions, feelings, and experiences. For this reason, contemporary studies focus on an individual person, his/her worldview, world perception, attitudes, needs, values, interests, etc.

The popular orientation as a method of oral history allowed studying not only today's people but also experience of persons in the past. This method provides the collection of personal data about the experience of events in the war period, their assessments, opinions, and feelings. Oral history can be an additional way of study.

The study of everyday life is a very topical issue in contemporary science (Narskii, 2007), especially in the period of the Great Patriotic War. The widespread issue about the Great Patriotic War is everyday life with its diverse aspects - dwelling, food, clothing, behaviour, mentality, culture, and recreation. The scientific study of recreation forms implies the examination of activities of cultural institutions directed at satisfaction of cultural needs and interests.

The issue of recreation during the period of the Great Patriotic War attracts researchers from different scientific fields of various regions. There is a series of comparative studies about the culture of the pre-war and war periods. L.I. Batyuk pays attention to the predominance of a patriotic nature of recreation of the war period instead of international ideas of the pre-war period. Performing arts and musical arts were focused on the formation of patriotic feeling in the fight against fascism of the war period (Batyuk, 2005: 20).

Several scientists study the activities of cultural institutions. They emphasise the patriotic role of the cinema during the war period (Maksakova, 1977: 31-33). Some of them note diverse difficulties for the effective activity of clubs, theatres, and cinemas due to reduc- tion in funding. Despite the problems, new art works were created. It was as a hope to win and a very strong motivation for the war and work achievements (Shmatov, 2003: 217). O.G. Zhukova writes about new methods in the activity of cultural institutions during the war period. Travelling exhibitions, agitation trains, ships, vans, mobile libraries, and theatres are among them (Zhukova, 2013: 21).

One of the common problems is the issue of recreation and cultural institutions activity, which were of great interest for diverse researches from the central part of the country. A.I. Nazarov compares different forms of recreation among the rural and urban youth in Tambov Oblast. In the countryside the youth's recreation was impacted by the traditional culture and peasant way of life. There were various forms of recreation for rural young people, such as the cinema, theatre, sport activities, competitions, and dances (Nazarov, 2010: 2122).

The study of recreation during the Great Patriotic War in Siberia is also a widespread field (studies about rural lifestyle, cultural institutions, and sociocultural environment). Despite the reduction of cultural processes intensity (state cinema decreased by two-thirds, the number of spectators halved) (Shalak, 2000: 367), cultural life of Siberia (especially the performing art) developed due to evacuation (famous persons were from the central part of the country) (Ziablitseva, 2011: 133, 419-420). Young people found time to have fun; they arranged "spot parties" with singing and dancing to the balalaika and guitar (Bukin, 1991: $32-40)$.

The first scientific works about recreation in the South of Krasnoyarsk Krai during the period of the Great Patriotic War appeared in the 1940s. General information about cultural life in Krasnoyarsk Krai is represented in diverse collective monographs of the 2000s (Zamyshliaev, 2010: 50-60; Elizov, 2012: 17).

S.P. Ulturgashev made the significant contribution into the study of the war period of the Khakass territory, particularly into the field of everyday life (Ulturgashev, 1963; Ulturgashev, 1987). Many other scientists explore the cultural life and recreation of Khakassia (Artamono- 
va, 2000; Liubimtseva, 1999; Troiakova, 2007; Tuguzhekova, 1993; Feoktistova, 2004; Lushnikov, 2014).

Thus, on the whole the issue of cultural life of different regions of the war period is sufficiently studied, despite the fact that the recreation and cultural interests of people are studied insufficiently. Besides, the present article focuses on the forms of recreations and cultural needs among the population of Khakassia and the South of Krasnoyarsk Krai during the war period.

\section{Theoretical framework}

The methodological basis of the study is "oral history". In the 1930s-1940s the given method was established by Allan Nevins in Columbia University as a unique method for the collection of memories of famous persons in American history (Perks, Thomson, 1998). The meaning of the method is in understanding of historical events by personal memories of eyewitnesses.

Oral history is a special method of data collection where a researcher and a interviewee are involved in the process of storytelling. Personal narrative can vary from a long to brief period of personal life. The unique feature of oral history is the study of personal lives from their point of view. How do they generate their own reality, produce personal experience, form life conditions, develop values, views, etc.? This method is truly relevant in interpretation cases of individual perception of significant social changes and incidents.

An evident advantage of oral history is the study of unavailable facts unrecorded in written sources. It allows expanding the opportunities of historical and sociocultural study of the past.

However, oral history is a very subjective method based on personal experience of a interviewee and its interpretation of a researcher. It causes doubts about the reliability of the collected data. Interviewees or participants of historical events often confuse dates, names, and facts. As a rule, interviewees remember very important events and circumstances for themselves or experiences which are still fresh in memory. Personal views are often connected with the current experience of the past instead of the experience which was valuable in the past.

In addition, it is necessary to note the situational frames of an interview - expectations of participants, conditions, purpose of a meeting, and other factors. The difficulty of the given method is caused by a transcription problem from verbal into written speech. Timbre, tempo, volume of voice, intonation, and pauses these characteristics impact the significance of storytelling. It is impossible to display it without a change of meaning.

The method of oral history also generates ethical problems. Firstly, it is a problem of responsibility for preservation and interpretation of the collected data. Secondly, it may cause moral damage. For example, some memories can be painful or too secret for interviewees.

Despite advantages and explicit disadvantages, oral history is successfully used in historical, anthropological, sociological and cultural studies, because it allows exploring individual experience within historical context. It is the result of convergence of historical, social, and cultural sciences.

\section{Methods}

The development of the method of "oral history" in Russia got widespread use during the period of the Great Patriotic War. The Commission on the Great Patriotic War's history was founded by the USSR Academy of Sciences in 1942. The heads of this Commission were G.F. Aleksandrov, Professor, Director of Agitation and Propaganda Section of the Central Committee of the CPSU (b) and Mints, the Corresponding Member of the USSR Academy of Sciences (Al'tman, 1991: 47-64).

The main purpose of the Commission was the collection of materials unrecorded in archives. The members of the Commission used methods of interview, transcribing storytelling, memories about the war and daily life. Participants of battles gave the most important information in the form of life stories of their commanders, political workers, and other soldiers.

After the war, the Commission was disbanded. At the present time 17422 archive 
works are grouped into 13 thematic chapters. The biggest array of private documents is in such chapters as "The Partisan Movement", "History of Military Units and Divisions", "Materials of History of the Defense of Moscow". These are mainly transcripts, interview notes, stories, memories of soldiers and commanders, manuscripts, diaries, letters, essays, poems, and songs enriching the database of the Great Patriotic War. These sources are very valuable for micro-historic processes, for the detailed reconstruction of the basis of everyday life, these historical sources enable us to explore everyday life.

The similar array was collected by different scientists of diverse regions of the country, particularly of Krasnoyarsk Krai and the Republic of Khakassia (Dorogi Pobedy..., 2005; Zdravstvuite!..., 2005; Minusintsy i Velikaia Otechestvennaia voina..., 2010, 2011, 2012, 2015).

The current work is based on the data of interviews of twenty peoples aged 78-88 years old from various settlements of the South of Krasnoyarsk Krai (12 men and 14 women). By the moment of the beginning of the war 18 interviewees lived in the rural area and 8 interviewees lived in the urban area. Only four interviewees had a job, while other interviewees attended different educational institutions (pedagogical college, school).

\section{Discussion}

This study is focused on the features of recreation during the Great Patriotic War in the territory of the South of Krasnoyarsk Krai and Khakassia. The article considers the forms of recreation through the prism of cultural needs and interests met by listening to the radio, reading books, newspapers and magazines, visiting museums, cinema, theatre, concerts, etc.

Many interviewees who lived in the countryside during that period, assert that their families did not have the radio. Only prosperous families had a radio set at home. As a rule, those families received different newspapers (district, regional ("Sovetskaya Khakasiya", "Khyzyl-Aal"), territorial ("Krasnoyarsky rabochy"), and central ones ("Pionerskaya Pravda", "Pravda", "Izvestiya").
Libraries are some of the most important cultural institutions. In the opinion of the majority of the interviewees, reading rooms, located in the mid-size and large villages, were not popular among the population. The archival data can explain reasons of that situation. Most reading rooms were closed due to the absence of librarians, lack of firewood, scarcity of a book stock and the absence of lighting, since libraries were used for other purposes (DDMH. Coll. 12. Aids. 12. Fol. 9. PP. 37-38).

Some reading rooms contained approximately 40-300 books, newspapers, and magazines (NARKH. Coll. R-169. Aids. 1. Fol. 328. PP. 44-45). Urban inhabitants had more opportunities for reading. According to the memoirs of interviewee, she liked reading books of Russian classics (works of Gogol and Pushkin) in the evenings in the light of stove (interviewee № 7).

Official sources about the forms of recreation in this territory during the war held little information. Only the library of Minusinsk Regional Museum of Local Lore named after N.M. Martyanov keeps data about the book stock. In the period of the Great Patriotic War the library had about 60 thousand books. Nearly 7-12 thousand readers visited the library. But they could read different literature only in reading rooms (AMKM. Coll. 1. Aids. 1. Fol. 455. P. 9; Fol. 603. P. 5; Fol. 606. P. 11; Fol. 608. P. 6; P. 613. P. 12, 27).

The majority of the interviewees who lived in the rural area, do not remember mobile cinemas, visiting theatre actors or amateur artists. Mobile performances often have come to large villages (Kokova, 1991). As a rule, visiting theatre and circus performances arrived in Abakan from Krasnoyarsk. For instance, the interviewee remembers: "In summer circus arrived in Abakan from Krasnoyarsk. I read about this in newspapers. I went to the cinema once.” (interviewee № 13).

Among visiting theatres there were the United State Dnepropetrovsk and Odessa Opera and Ballet Theatres, Krivorozhsk Ukrainian Drama Theatre of the October Revolution, the Ukrainian Theatre of Musical Comedy and Drama of Molotov Regional De- 
partment of Arts, the Theatre of Musical Comedy Midgets, Circus tent, stage masters from the All-Union Bureau of Stage. They showed series of performances in Abakan, Chernogorsk, Minusinsk and other towns in the territory of the South of Krasnoyarsk Krai. Let us mention some of those performances such as "Oi, ne khody Gritsu tai vechernitsy" ("Oh, Don't Go to Gritsu in The Evenings"), "Natalka-Poltavka", "Tsyganka Aza" ("Gypsy Aza") (Krasnoyarskii rabochii, 1943), "Bestalanna" ("Untalented"), "Zaporozhets za Dunaem" ("A Zaporozhian beyond the Danube"), "Svad'ba v Malinovke" ("The Wedding in Malinovka") (Sovetskaia Khakassiia, 1941), "Roz-Mari”" ("Rose Marie"), "Fialka Monmartra" ("The Violet of Montmartre"), "Krasnaia shapochka" ("Little Red Riding Hood"), etc.

Local theatres carried out effective activity as well. The Khakass National Theatre showed plays in the Khakass language based on the works by M.S. Kokov and A.M. Topanov - "Akun", "Stalnye serdtsa" ("Steel Hearts"), "Iuny geroi" ("The Young Hero"), "Krov' za krov"” ("Blood for Blood"), "Odurachennyi Khorkhlo" ("Fooled Khorkhlo") (NARKH. Coll. 169. Aids. 1. Fol. 290. PP. 107-108). Regional Drama Theatre had an extensive repertoire of Russian and foreign classics - "Bez viny vinovatye" ("Guilty Without Guilt"), "Maskarad" ("Masquerade"), "Khoziaika gostinitsy" ("The Landlady"), "Mary Tudor", "Machekha" ("Stepmom"), "Zhenit'ba Figaro" ("The Marriage of Figaro"), "Prodolzhenie sleduet" ("To Be Continued"), "Birthday", "Paren' iz nashego goroda" ("A Lad from Our Town"), "Nashestvie" ("Invasion"), etc. (Artamonova, Lushnikov, 2016). The price of a theatre ticket ranged from 8 to 13 rubles (Artamonova, 2012). It is very expensive in comparison with the price of a cinema ticket. The interviewee remembers: "A ticket to the cinema in Chernogorsk was cheap, it was 15 kopecks." (interviewee № 24).

It explains the high cinema attendance in that period. New movies were shown regularly, twice a week. "Sem'ia Oppengeim" ("The Oppenheim Family"), "Kain and Abel", "Tanker Derbent", "Timur and His Squad", "Combat Movie Collections", "A Great Life", "Anton
Ivanovich Is Angry", "The Defeat of The German Forces Near Moscow", etc. were among them.

There is data about concert tours of gypsy artists, artists of the Union Tour and Concert Association, Alma-Ata Philharmonic Orchestra, Kiev singers (Elga Arens, violin Joseph Kogan, piano Simon Kogan).

A part of interviewees remember about dancing to the concertina, accordion, and bayan music (interviewee № 6, 16, 24, 26 ). The interviewee remembers: "We enjoyed the concertina and danced polka and krakowiak" (interviewee № 26). But few of them visited dances due to the lack of decent clothes (interviewee № 2, 7, 10).

The unique practice in the countryside was spontaneous evening meetings. They involved a concertina player, dancing and singing (interviewee № 3, 22). The interviewee says about evenings when young girls and women knitted socks for soldiers (interviewee № 11). In interviewee's memoirs a brass band was in the collective farm of village Troitskoe (interviewee № 10). It was a gift to people for their work achievements. This brass band played while sending soldiers to the front.

An important part of everyday life was interpersonal communication after non-working hours, and especially during celebrations. All interviewees remember the holidays (May $1^{\text {st }}$, November $7^{\text {th }}$, Easter, Christmas and New Year). They dyed eggs with onion peel, made toys, decorated the New Year tree, have prepared modest gifts. For some people personal communication was a single form of recreation necessary for moral recovery at that hard time.

\section{Conclusion}

Thus, the method of oral history allows clarifying particularly useful information and expanding the data of other sources in the process of studying everyday life during the Great Patriotic War. In particular, there are significant differences between official reports and information from the interviewees.

The study of recreation forms during the war period reveals its various forms. There are reading books, newspapers (mainly regional 
and sometimes central) and magazines in libraries, listening to the radio, going to the theaters and circus (both local and visiting), and mobile cinemas. Evening dancing parties to live concertina, accordion or bayan music, and in some places to the brass band can be called a special form of recreation

These studies found differences between the recreation activities of urban and rural people. Obviously, urban inhabitants had more opportunities for diverse recreation because of variety of cultural life, accessibility and low ticket prices. Rural people had fewer opportunities for recreation activities. For example, in rural areas most libraries were closed due to the lack of funding. Even though visiting theatres, circus and mobile cinemas came with tours to the countryside, they mainly visited large villages or settlements. During that period evacuation also impacted the development of cultural institutions. Holidays were an important part of everyday life. Many interviewees remember some details in the process of preparation for their celebration.

Interpersonal communication, which allowed people to relax, to rest and to share their experiences and emotions with other people, plays a very important, and perhaps, key role. Thus, despite the war, people found diverse ways to relax and meet their cultural needs and interests.

It is necessary to continue collecting memories of people who lived in that war period. The number of participants and witnesses of the Great Patriotic War has reduced. We have the last chance to reveal and preserve valuable information about everyday life of those people, their experiences, views, and feelings for the future generation.

The list of interviewees (interview was conducted by V.K. Lushnikov, survey geography: Khakassia):

1. Antonovich Elizaveta Anisimovna 23.02.1926 year of birth, interview was conducted on 22.12.2016 in Abakan.

2. Burika Iakov Dem'ianovich 16.01.1929 year of birth, interview was conducted on 07.08.2012 in Troitskoe by Bograd district.

3. Cheltyshev Sergei Vladimirovich 20.03.1926 year of birth, interview was con- ducted on 22.11.2012 in Kop'evo by Ordzhonikidzev district.

4. Dobrov Semen Timofeevich 27.04.1929 year of birth, interview was conducted on 30.05.2012 in Novomar'iasovo by Ordzhonikidzev district.

5. Grishkova Kseniia Nikolaevna 31.01.1925 year of birth, interview was conducted on 22.03.2017 in Abakan.

6. Korzun Mariia Antonovna 15.08.1922 year of birth, interview was conducted on 17.10.2012 in Shira.

7. Krivonogova Zinaida Mikhailovna 08.11.1928 year of birth, interview was conducted on 05.08.2012 in Minusinsk.

8. Kuzhakov Georgii Prokop'evich 10.05.1924 year of birth, interview was conducted on 02.05.2012 in Anchul by Tashtip district.

9. Kyzlasova Klara Romanovna 31.08.1927 year of birth, interview was conducted on 22.03.2017 in Abakan.

10. Mal'tseva Vera Grigor'evna 12.10.1923 year of birth, interview was conducted on 07.08.2012 in Troitskoe by Bograd district.

11. Mazniakova Antonida Anatol'evna 26.03.1934 year of birth, interview was conducted on 12.08.2015 in Kalinino by UstAbakan district.

12. Mikheeva Valentina Aleksandrovna 14.03.1927 year of birth, interview was conducted on 21.09.2012 in Abakan.

13. Miller Nina Alekseevna 21.06.1922 year of birth, interview was conducted on 21.12.2016 in Abakan.

14. Morozov Georgii Gavrilovich 09.05.1927 year of birth, interview was conducted on 26.12. 2017 in Chernogorsk.

15. Netepenko Elena Grigor'evna 19.01.1930 year of birth, interview was conducted on 21.09.2012 in Abakan.

16. Ol'khovik Tais'ia Vasil'evna 05.03.1928 year of birth, interview was conducted on 26.11.2016 in Chernogorsk.

17. Piskunov Evgenii Il'ich 26.05.1924 year of birth, interview was conducted on 08.09.2017 in Abakan.

18. Ponomareva Zoia Vasil'evna 08.03.1932 year of birth, interview was conducted on 03.05.2011 in Tashtip by Tashtip district. 
19. Putintseva Valentina Lavrent'evna 22.02.1929 year of birth, interview was conducted on 22.06.2012 in Abakan.

20. Romanova Anna Ivanovna 20.12.1926 year of birth, interview was conducted on 22.05.2012 in Chernogorsk.

21. Tepliashin Nikolai Trofimovich 21.12.1933 year of birth, interview was conducted on 11.03.2017 in Minusinsk.

22. Turtugeshev Innokentii Filippovich 05.12.1925 year of birth, interview was conducted on 02.03.2011 in Balyksa by Askiz district.
23. Shatalov Semen Ermolaevich 13.09.1930 year of birth, interview was conducted on 10.10.2017 in Abakan.

24. Shushenachev Innokentii Vasil'evich 26.02.1923 year of birth, interview was conducted on 06.12.2012 in Abakan.

25. Shevchenko Petr Ivanovich 23.09.1928 year of birth, interview was conducted on 03.09.2016 in Minusinsk.

26. Vasil'ev Prokopii Egorovich 11.09.1929 year of birth, interview was conducted on 21.09.2012 in Abakan.

\section{References}

Al'tman, M.M. (1991). Organizatsiia sobiraniia i ispol'zovaniia dokumentov lichnogo proiskhozhdeniia o Velikoi Otechestvennoi voine: Iz opyta raboty TSGA SSSR i gosudarstvennykh arkhivov $R F$ [The Organisation of Collection and Using of Personal Papers of the Great Patriotic War: From the Experience of the CSA of the USSR and The State Archives of the Russian Federation]. Moscow, 204 p.

Arkhiv Minusinskogo regional'nogo kraevedcheskogo muzeia imeni N.M. Mart'ianova [The Archives of the Minusinsk Regional Museum of Local Lore named after N.M. Martyanov]. (AMKM). Collection 1. Aids 1. Folder 455. PP. 9; Folder 603. PP. 5; Folder 606. PP. 11; Folder 608. PP. 6; PP. 613. PP. 12, 27.

Artamonova, N.Ia. (2000). Intelligentsiia Vostochnoi Sibiri: opyt formirovaniia i deiatel'nosti (konets $X I X$ - seredina XX vv.) [Intellectuals of Eastern Siberia: The Experience of Formation and Activity (late $19^{\text {th }}-$ mid $20^{\text {th }}$ centuries)]. Moscow, Prometei, $237 \mathrm{p}$.

Artamonova, N.Ia. (2012). Teatral'noe iskusstvo v Khakasii v gody Velikoi Otechestvennoi voiny [Theatre Art in Khakassia in the Period of the Great Patriotic War]. In Vestnik Khakasskogo gosudarstvennogo universiteta [The Bulletin of Katanov State University of Khakassia], 1, 42-46.

Artamonova, N.I., Lushnikov, V.K. (2016). Teatral'noe iskusstvo v povsednevnoi zhizni naseleniia Khakasii v gody Velikoi Otechestvennoi voiny [Theatre Art in Everyday Life of Population of Khakassia in The Period of the Great Patriotic War]. In Problemy sotsial'no-ekonomicheskogo razvitiya Sibiri [Problems of Socio-Economic Development of Siberia], 3 (25), 75-81.

Batyuk, L.I. (2005). Kul'tura Rossii v gody Velikoi Otechestvennoi voiny [The Culture of Russia in the Period of the Great Patriotic War]. Moscow, 22 p.

Bukin, S.S. (1991). Opyt sotsial'no-bytovogo razvitiia gorodov Sibiri (vtoraia polovina 1940-1950 gg.) [The Experience of Socio-Household Development in Siberian Cities (The Second Half of the 1940s and 1950s)]. Novosibirsk, Nauka, 238 p.

Dorogi Pobedy. Vospominaniia krasnoyartsev-vereranov fronta i tyla Velikoi Otechestvennoi voiny 1941-1945 gg. [Ways of the Victory. Memories of Krasnoyarsk Veterans of the Front and Rear of the Great Patriotic War of 1941-1945s] (2005). Krasnoyarsk, Krasnoyarsk Publisher, 296 p.

Elizov, A.G. (2012). Povsednevnnaia zhizn' gorodskogo naseleniia Krasnoyarskogo kraia v seredine 1940-h - seredine 1960-h gg. [Everyday Life of Urban Population of Krasnoyarsk Krai in the Middle of $1940 \mathrm{~s}-1960 \mathrm{~s}$. Irkutsk, $26 \mathrm{p}$.

Feoktistova, T N. (2004). Istoriia stanovleniia i razvitiia muzeinogo dela v Khakasii v XX veke: 19282003 [The History of Establishment and Development of Museums in Khakassia in the 20 ${ }^{\text {th }}$ century: 19282003]. Abakan, 196 p.

Gosudarstvennoe kazennoe uchrezhdenie Respubliki Khakasiya "Natsional'nyi arkhiv" [State Institution of the Republic of Khakassia "The National Archives”]. (NARKH). Collection R-169. Aids 1. Folder 328. PP. 44-45. Collection 169. Aids 1. Folder 290. PP. 107-108. 
Kokova, E.M. (1991). Chon charii. Iz istorii Khakasskogo dramaticheskogo teatra [Chon Charii. From the History of the Khakass Drama Theatre]. Abakan, Khakass Publisher, 168 p.

Kostiakova, Iu.B. (2007). Stanovlenie i razvitie sistemy massovogo radioveshchaniia v natsional'nykh raionakh Iuzhnoi Sibiri (1928-1961) [The Establishment and Development of the System of Mass Radio Broadcasting in the Ethnic Regions of Southern Siberia (1928-1961)]. Abakan, 197 p.

Krasnoyarskii rabochii [The Krasnoyarsk Worker], 1943, 31 of December.

Liubimtseva, O.Iu. (1999). Kul'turno-prosvetitel'skaia rabota v Khakassii (1941-1965 gg.) [The Cultural and Educational Activity in the Khakassia (1945-1965s)]. Abakan, 24 p.

Lushnikov, V.K. (2014). Kul'turnaia zhizn' naseleniia iuga Krasnoyarskogo kraia v gody Velikoi Otechesstvennoi voiny [Cultural Life of Population of the South of Krasnoyarsk Region in the Period of Great Patriotic War]. In Mart'ianovskie kraevedcheskie chteniya (2012-2013 gg.) [Mart'ianov Readings (2012-2013s)]. Minusinsk, 8, 265-269.

Maksakova, L.V. (1977). Kul'tura Sovetskoi Rossii v gody Velikoi Otechesstvennoi voiny [The Culture of Soviet Russia in the Period of the Great Patriotic War]. Moscow, Nauka, $343 \mathrm{p}$.

Minusintsy i Velikaia Otechestvennaia voina... [Minusinsk People and the Great Patriotic War...] (2010). Ed. L.N. Ermolaeva. Abakan, Zhurnalist, 128 p.

Minusintsy i Velikaia Otechestvennaia voina... [Minusinsk People and the Great Patriotic War...] (2011). Ed. L.N. Ermolaeva. Abakan, Zhurnalist, 272 p.

Minusintsy i Velikaia Otechestvennaia voina... [Minusinsk People and the Great Patriotic War...] (2012). Ed. L.N. Ermolaeva. Abakan, Zhurnalist, 220 p.

Minusintsy i Velikaia Otechestvennaia voina... [Minusinsk People and the Great Patriotic War...] (2015). Ed. L.N. Ermolaeva. Abakan, Zhurnalist, 308 p.

Narskii, I.V. (2007). Novyi fundamental'nyi trud o rossiiskoi povsednevnosti [The New Fundamental Work on Russian everyday life]. In Otechestvennaia istoriia [National History], 4, 158-164.

Nazarov, A.I. (2010). Povsednevnnaia zhizn' molodezhi v sovetskom tylu v gody Velikoi Otechesstvennoi voiny 1941-1945 gg. (Na materialah Tambovskoi oblasti [Everyday Life of Youth in The Soviet Rear in the Period of Great Patriotic War 1941-1945s. On the Materials of Tambov Region]. Tambov, $24 \mathrm{p}$.

Otdel dokumentov noveishei istorii [Department of Documents of Modern History]. (DDMH). Collection 12. Aids 12. Folder 9. PP. 37-38.

Orlov, I.B. (2014). Teoriia i metodologiia istorii [The Theory and Methodology of History]. Volgograd, Uchitel', $504 \mathrm{p}$.

Perks, R., Thomson, A. (1998). The Oral History Reader. London and New York, Routledge, 480 p.

Shalak, A.V. (2000). Usloviia zhizni naseleniia Vostochnoi Sibiri (1940-1950 gg.) [Life Conditions of the Population of Eastern Siberia (1940-1950s)]. Irkutsk, 464 p.

Shmatov, V.N. (2003). Goroda Srednego Povolzh'ia v period Velikoi Otechestvennoi voiny [Cities of the Middle Volga Region in the Period of the Great Patriotic War]. Samara, $256 \mathrm{p}$.

Sovetskaia Khakassiia [The Soviet Khakassia], 1941, 15, 17, 29 of October; 1, 25 of November; 15, 16, 18 of December.

Troiakova, Iu.K. (2007). Hudozhestvennaia intelligentsiia natsional'nyh raionov Yuzhnoi Sibiri: problemy formirovaniia i rosta (1945-1965 gg.) [Artistic Intellectuals of the Ethnic Regions of the Southern Siberia: Problems of Formation and Growth (1945-1965s)]. Abakan, 26 p.

Tuguzhekova, V.N. (1993). Iuzhnaia Sibir': poslevoennaia 1945-1965 gg. [The Southern Siberia: PostWar 1945-1965s]. Abakan, Khakass Publisher, 194 p.

Ulturgashev, S.P. (1963). Khakassiia v gody Velikoi Otechesstvennoi voiny Sovetskogo Soiuza (iiun' 1941 goda - 1945 goda [Khakassia in the Period of Great Patriotic War (June of 1941s-1945s)]. In Ocherki istorii Hakasii sovetckogo perioda [Essays of the History of Khakassia Soviet Period], 198-229.

Ulturgashev, S.P. (1987). Khakasskaia oblastnaia partiinaia organizatsiia v period Velikoi Otechesstvennoi voiny (1941-1945) [The Khakass Regional Party Organization in the Period of Great Patriotic War 1941-1945s]. In Ocherki istorii Khakasskoy oblastnoi organizatsii KPSS [Essays on the History of the Khakass Regional Organization of the CPSU], 140-186. 
Zamyshliaev, V.I. (2010). Sotsial'no-kul'turnyi potentsial Kracnoyarskogo kraya v gody Velikoi Otechesstvennoi voiny 1941-1945 gg. [Sociocultural Potential of Krasnoyarsk Region in the Period of Great Patriotic War 1941-1945s]. In Sibirskii subetnos: kul'tura, traditsii, mental'nost': materialy VI Vserossiiskoi nauchno-prakticheskoi Internet-konferentsii na saite sib-subethnos.narod.ru / ed. N. I. Drozdov [Siberian Subethnos: Culture, Traditions, Mentality: Materials of the VI All-Russian Scientific and Practical Internet Conference on the Website sib-subethnos.narod.ru / ed. N. I. Drozdov]. Krasnoyarsk, 50-60.

«Zdravstvuite!...» Frontovye pis'ma 1941-1945 gg. [Hello!... Letters from the Front] (2005). Abakan, Platina, $301 \mathrm{p}$.

Zhukova, O.G. (2013). Povsednevnnaia zhizn' sovetskogo tyla v usloviiah Velikoi Otechestvennoi voiny 1941-1945 gg.: istoricheskie i sotsial'no-kul'turnye aspekty [Everyday Life of the Soviet Rear in the Period of the Great Patriotic War 1941-1945: Historical and Socio-Cultural Aspects]. Moscow, 24 p.

Ziablitseva, S.V. (2011). Sotsiokul'turnyi potentsial Zapadnoi Sibiri i praktika ego realizatsii (1920$h$ - seredina 1950-h gg.) [Sociocultural Potential of Western Siberia and the Practice of its Realization (1920s - middle of 1950s)]. Kemerovo, Publisher of KemGUKI, 472 p.

\title{
Изучение форм досуга в период Великой Отечественной войны методом устной истории
}

\author{
О.Л. Лушникова ${ }^{a}$ В.К. Лушников \\ аХакасский научно-исследовательский институт языка, \\ литературы и истории \\ Российская Федерачия, Республика Хакасия, Абакан \\ ${ }^{6}$ Хакасский государственный университет им. Н.Ф. Катанова \\ Российская Федерачия, Республика Хакасия, Абакан
}

\begin{abstract}
Аннотация. Статья посвящена исследованию форм досуга населения на территории юга Красноярского края в период Великой Отечественной войны. Цель данного исследования состоит в формировании общих представлений о формах досуга людей в этот сложный период. Достаточно много количественных исследований, посвященных досугу в военное время, однако для более глубокого понимания жизни людей в этот период лучше использовать качественные исследования. Для этой цели более целесообразным является метод устных историй, который позволяет исследовать непосредственный опыт людей в прошлом. Несмотря на субъективный характер, этот метод позволяет вскрыть недоступные факты, не зафиксированные в каких-либо письменных источниках. Содержание этой статьи основано на данных интервью 26 человек (в возрасте 78-88 лет), проводившихся с 2011 по 2017 годы Кроме того, в исследовании использовались данные архивных источников.

Проведенный анализ позволил обрисовать общую картину того, каким был досуг в годы войны на территории юга Красноярского края. Во-первых, исследование выявило разнообразие форм досуга. Это и чтение книг, прослушивание радио, походы в театр и цирк (как местный, так и приезжий), посещение киносеансов, в т. ч. передвижек. Особой формой досуга можно назвать вечёрки - танцы под гармошку, аккордеон, баян, а в некоторых местах и под духовой оркестр. Во-вторых, данные исследования обнаружили различия между городским и сельским досугом. У сельских жителей, как правило, было меньше возможностей для проведения досуга. К примеру, в сельской местности большая часть библиотек была закрыта
\end{abstract}


из-за отсутствия возможности их содержать. В-третьих, немаловажную роль играло межличностное общение, которое позволяло людям расслабиться, отдохнуть и поделиться своими впечатлениями и эмоциями с другими людьми.

Ключевые слова: формы досуга, Великая Отечественная война, устная история, воспоминания, культурная жизнь.

Научные специальности: 07.00.00 - исторические науки, 22.00.06 - социология культуры. 